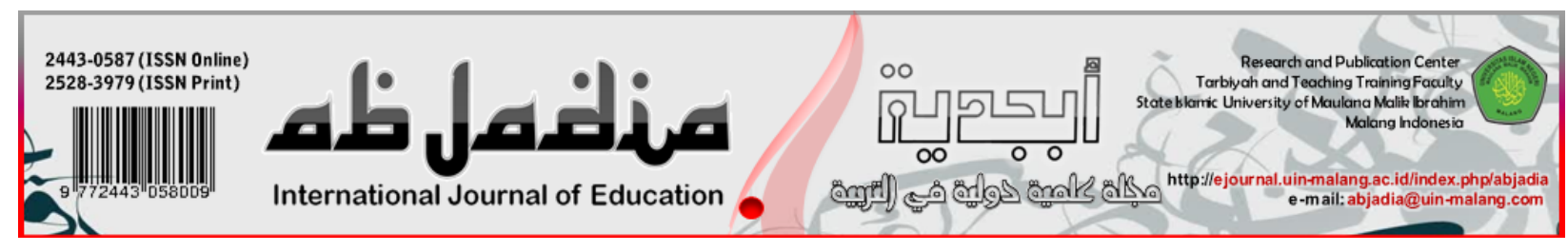

\title{
AL-WASHLIYAH EDUCATIONAL COUNCIL POLICY IN THE DEVELOPMENT OF MADRASAH ALIYAH CURRICULUM IN NORTH SUMATERA
}

\author{
Mursal Aziz 1, Syafaruddin 2, Mesiono ${ }^{3}$ \\ 1STIT Al-Ittihadiyah Labuhanbatu Utara, Indonesia \\ 2,3 Universitas Islam Negeri Sumatera Utara, Indonesia
}

Article History:

Received : 2019-06-23

Revised : 2019-06-24

Accepted : 2019-06-24

Published : 2019-06-30

\section{Keywords:}

Policy, Curriculum Development, Madrasah

\section{Correspondence Address:} mursalaziz7@gmail.com syafaruddinsiahaan@uinsu.ac.id mesiono@uinsu.ac.id

\begin{abstract}
Education policy is one of the determinants of an organization in determining the educational goals. Al-Washliyah is one of the largest Islamic organizations in North Sumatera that has many educational institutions whose role is to help to educate the community. A good educational management through the strategic policies will produce the good graduates. The role of the Al-Washliyah Educational Council in making curriculum development policies for Madrasah Aliyah (Islamic Senior High School) in North Sumatera is very urgent. One of the determinants of the success of the objectives of Islamic education at the Al-Washliyah educational institutions is the policy of developing Madrasah Aliyah Al-Washliyah curriculum taken by the Al-Washliyah Educational Council. The Al-Washliyah Educational Council policy in developing Islamic education curriculum was by establishing the implementation of the policies in the form of Decree. Among the strategic policies taken by the Al-Washliyah Educational Council were the Al Washliyah curriculum, Al-Washliyah Educationsl System (SPA), the Diniyah Curriculum and additional curriculum for Islamic Religion subject. The purpose of this study was to find out how the characteristics of the AlWashliyah Educational Council policies in developing Madrasah Aliyah Curriculum in North Sumatera.
\end{abstract}

\section{C) Introduction}

Madrasah is one of the important Islamic educational institutions in responding to the needs of the community. The presence of madrasah emerged in the late nineteenth century, not to denied in the early period of its development, madrasah tended to compete with Dutch education offered by the colonial government and became a symbol of Islamic reform. Madrasah is an Islamic educational institution that teaches Islamic and general subjects, uses a scoring system, and simultaneously offers the certificates to the graduates. In the Indonesian context, madrasah is the combination of pesantren (Islamic boarding school) and schools (Azra et al., 2010: 126). This is the factor of public interest in madrasah because it combines Islamic and public education. Today, madrasah is an Islamic educational institution that is in demand because the transformation in the 
development of Islamic educational curriculums is appropriate to the needs of Islamic education.

The educational system in Indonesia is the fourth largest in the world. Although the data on the actual number of Islamic schools (madrasah and pesantren) in this country is different. The Ministry of Religion claims to manage around 45,000 in 2010. More than 90 percent of them are private schools, many of which were established by local communities. Communities or foundations of Islamic society manage without the existence of alternatives sponsored by the State. Private Madrasah funded primarily by the community, manage and provide nine-year compulsory education including AlWashliyah Madrasah. These institutions have 6 million students consisting of 3.5 million students from 22,000 Islamic elementary schools (Madrasah Ibtidaiyah) and 2.5 million students in 14,000 Madrasah Tsanawiyah (Suryadarma and Jones, 2013: 68). This number includes the Madrasah Aliyah Al-Washliyah Madrasah. This proves that Al-Washliyah has an essential role in Islamic education.

Al-Washliyah as one of the largest Islamic organizations in North Sumatra has a variety of educational institutions, ranging from the lowest in the form of childhood Islamic education and Madrasah Ibtidaiyah to the highest level, namely universities. Based on the responsibility of the geographical location where the position of AlWashliyah was born and developed in North Sumatra, the organization has a high enthusiasm to take part in building Islamic education in North Sumatra through educational institutions and the development of good curriculum.

The education curriculum at Madrasah Aliyah Al-Washliyah has its characteristics and has several distinctions with several other Islamic Madrasah in North Sumatra. Even the unique fellow Al-Washliyah educational institutions have different curriculum development or have distinctive features and patterns of The Madrasah. It is because the response of the madrasah is different to the needs of the community and the demands of needs and changes in the curriculum carried out by the government, so most of Madrasah Aliyah Al-Washliyah also develop their curriculum as an adjustment to the policy rules set by the government.

The policies taken by the management of Al-Washliyah relating to the curriculum are slightly different from the initial goals of Al-Washliyah education whose purpose is to engender to prospective scholars who enlighten the spiritual community. With the changes in curriculum development that are more inclined to general subjects, the pioneer of ulama (scholars) produced by Al-Washliyah educational institutions is not optimal and even very rare.

Through the Al-Washliyah Educational Council policy, it hoped that madrasah Aliyah can run the teaching and learning process well. The Al-Washliyah Educational Council policy will direct madrasah Aliyah in North Sumatra properly to be able to develop the madrasah curriculum well by the needs of the people who entrust their children to study in Al-Washliyah educational institutions, especially Madrasah Aliyah. 


\section{QQ Method}

This study used a qualitative research method, which is the research procedures that produce descriptive data in the form of written or oral words from people and observable behavior. In the study of the implementation of the Al-Washliyah Educational Council policy in the development of Islamic educational curriculum in North Sumatera, in-depth disclosure of data through interviews, observations and document studies on what the research subjects/informants did was related to the implementation of the AlWashliyah Educational Council policy in developing Islamic educational curriculum in North Sumatra with qualitative research method.

The qualitative research approach, as a scientific method, is often used and implemented by a group of researchers in the field of social sciences, including education and management education. Several reasons also raised, which essentially point out that qualitative research enriches the results of quantitative research. Qualitative research is carried out to build knowledge through understanding and discovery. This qualitative research approach is often called naturalistic research methods because this research is carried out in natural conditions or natural settings (Sugiono, 2014: 1).

Qualitative methods in research according to Lexy J Moleong (2008: 5) are carried out with several considerations, namely: the first, adjusting qualitative methods is easier when dealing with multiple realities; the second, this method presents the nature of the relationship between the researchers and respondents directly; the third, this method is more sensitive and more able to adjust to a lot of sharpening of shared influence and the patterns of value faced.

Bogdan and Taylor explained that qualitative research methodology is a research procedure that produces descriptive data in the form of written or oral from people and observable behavior (Moleong, 2008: 5). A researcher in qualitative research speaks directly and observes several people, and interacts for several months to study the background, habits, behavior, and physical and mental characteristics of the person studied. The characteristics of qualitative research According to Bogdan and Biklen (1982: 28), namely: (1) natural, (2) descriptive data rather than numbers, (3) inductive data analysis, and (4) meaning is very important in qualitative research. Thus, the research on the policy of the Al-Washliyah Educational Council in the development of the Madrasah AliyahAl-Washliyah curriculum in North Sumatera fulfilled the characteristics of qualitative research, especially in terms of disclosure of in-depth data through interviews, observations and document studies on what research subjects/ informants, how they carried out the activities, for what the activities were carried out, and the matters relating to the implementation of the Al-Washliyah Educational Council policy in the development of the Madrasah Aliyah Al-Washliyah curriculum in North Sumatera with qualitative research method.

The data collection techniques of qualitative research methods in this study are: 
1. Interviews, namely conversations with specific intentions carried out by two parties, namely the interviewer who asks the question, and the interviewee who provides answers to the question so that information is obtained related to the research (Moleong, 2008: 135).

2. Observation, namely the ability of a person to use his observations through the work of the senses of the eye and assisted by other senses. Observation is also used as the main method, in addition to unstructured interviews, to collect the data (Bungin, 2011:138).

3. Document analysis, namely any written material or film, both personal and official as the data source that can be used to test, interpret, and even predict something.

The sample in this study was three Madrasah Aliyah in North Sumatera purposively. The purposive procedure in qualitative research is a strategy for determining the most common informants, namely determining groups of participants who become informants according to the selected criteria that are relevant to research problems (Bungin, 2011: 107). Based on the consideration of selecting samples or informants based on the selected criteria in the form of curriculum differences, three madrasah were chosen representing the selected criteria in the form of curriculum differences that were used, namely Madrasah Aliyah Mu'allimin Univa Medan (Diniyah Al-Washliyah Curriculum, Soul Sciences and Tarbiyah Sciences), Madrasah AlWashliyah Qismul 'Aly (Diniyah Al-Washliyah curriculum, Ad-Diyan and Mantiq) and Medan Univa Madrasah Aliyah (National / government curriculum).

\section{Result}

Many policies of the Al-Washliyah Educational Council were taken in the development of the Madrasah Aliyah curriculum in North Sumatera. The policy was formulated through deliberations and meetings, made a decision letter, then socialized it. As for the Al-Washliyah Educational Council's strategic policy in developing the Madrasah Aliyah curriculum in North Sumatera, namely:

\section{Al Washliyah Learning Curriculum}

The Al-Washliyah subject is a compulsory subject at Madrasah Al-Washliyah. This is by the Education Council Decree PB Al-WAshliyah Number: Kep-001/MP.P$\mathrm{AW} / \mathrm{XXI} / \mathrm{X} / 2018$ dated October 30, 2018. One of the decisions of the Decree is the Al Washliyah subject must be carried out consistently at SD/MI, SMP/MTS, MA/SMK/SMA while still opening opportunities for educators to innovate.

Regarding the subject of Al-Washliyah, the scope of the discussion material in Al-Washliyah curriculum consists of the components/aspects as follows:

a. Organization of al-Jam'iyatul Washliyah;

b. History of Establishment;

c. The foundation of faith and worship; 
d. Symbols and songs;

e. Its work in the field of propaganda and social.

The Al-Washliyahan subject curriculum is compiled based on the basic curriculum and structure of the 2013 curriculum, which consists of Core Competencies (KI) and Basic Competencies. Core competencies are designed along with the increasing age of the students in certain classes. Through the core competencies, the vertical integration of various basic competencies in different classes can be maintained.

\section{Implementation of Imtihan Umumy (general examination)}

Imtihan Umumy examination is just like the Al-Washliyah National Examination. Each madrasah under the auspices of the Al-Washliyah Educational Council is obliged to carry out the Imtihan Umumy. This Imtihan Umumy is a test for the curriculum that applies the Diniyah curriculum because in Imtihan Umumy it is by the subjects and material in the Diniyah curriculum. Therefore all Madrasah Aliyah Mu'allimin and Qismul 'Aly took Imtihan Umumy. For students in madrasah which does not use the Diniyah curriculum also follow Imtihan Umumy, but specifically for the subject of AlWashliyah.

Imtihan Umumy is a test conducted annually at Madrasah Al-Washliyah. This test is principally the same as the National Examination. Engaging in ImtihanUmumy 20182019 The Educational Council of the Al-Washliyah Executive Board has issued Decree No. Kep-003/MP.PB-AW/XXI/II/2019 concerning the National Committee for ImtihanUmumy Al-Washliyah 2018-2019 Academic Year after considering the Letter of the Education Council of the Executive Board of Al-Washliyah No. Int.024/MP.PBAW/XXI/II/2019 dated February 1, 2019, concerning the Implementation of ImtihanUmumy for the 2018-2019 Academic Year and considering the Al-Washliyah Executive Board of Education Board Meeting on February 5, 2019.

\section{Diniyah Curriculum}

The Diniyah curriculum used by Al-Washliyah uses the books in Arabic (classic book). As for the subjects in the Diniyah Curriculum, namely: At-Tafsir with learning resources of the Tafsir Jalalayn book; Al-Hadis with learning resources from the book Jawahirul Bukhari; At-Tārikh with learning resources of the book Nur al-Yaqin Fi Shirah Sayyid al-Mursalin; Al-Tauhìd with the learning resources of the book Al-Hud Hudi; AnNahwu with learning resources of the book Al-Kawakib Durriyah; Al-Fiqh with the learning source of the book al-Mahalli; Al-Balaghah with learning resources from the book Jawahir al-Balaghah; Ușul al-Figh with learning resources book Ushulul Figh 'Abdul Wahhab Khallaf; Qawäid Al-Fiqhiyah with learning resources Al-Qawa'id al-Fiqhiyyah Al-Hajj Muhammad Arsyad Thalib Lubis; Akhlaq with learning resources of the book Mau'izhatul Mukminin; AlAdyān with learning resources of the book Al-Adyān Muhammad Yunus; Mantiq with book learning resources al-Manthiq Ta'lif Muhammad Nur Ibrahimy; soul sciences with learning 
resources that are considered appropriate by the teachers; Tarbiyah Science with the learning resource or the books that are considered appropriate by teachers.

Al-Washliyah educational institutions that use the Diniyah curriculum is madrasah Mu'allimin and Qismul 'Ali. This type of Madrasah is an Al-Washliyah Madrasah that uses Al-Washliyah curriculum which applied Arabic besides the National curriculum set by the government. Although Mu'allimin and Qismul 'Aly both use the Diniyah Al-Washliyah curriculum, between the two types of this madrasah also have differences. The difference is that the Mu'allimin madrasah teaches the science of tarbiyah and the science of the soul while madrasah Qismully 'Aly does not, but it teaches the Sciences of Mantiq and Ad-Diyan that are not studied in the Mu'allimin madrasah. Besides madrasah Mu'allimin and madrasah Qismul 'Aly, there are also Aliyah Madrasah in general which only use the National curriculum coupled with the local content of Al Washliyah curriculum development; this madrasah is an Islamic school.

The Al-Washliyah educational institutions that implement the diniyah curriculum are Madrasah Aliyah Mu'allimin and six madrasah Aliyah Qismul 'Aly namely: MAQ Al-Washliyah 12 Perbaungan, MAQ Al-Washliyah Jl. Ismailiyah, MAQ Al-Washliyah Tanjung Beringin, MAQ Al-Washliyah Nagar, MAQ Al-Washliyah Kedaisianam, MAQ Al-Washliyah Tanjung Tiram. These madrasah using the diniyah Islamic curriculum are expected to be candidates for future ulama.

\section{jiin Discussion}

Educational policy according to Tilaar (2009: 7) is a formulation of various ways to realize the goals of national education, realized or achieved through social institutions or social organizations in the form of formal, non-formal, and informal educational institutions. The policy is a set of goals, principles, and regulations that guide an organization. The system, thus, covers the entire organization's instructions. System is the result of top management decisions that are made carefully, which essentially form the goals, principles, and rules that direct the organization (Syafaruddin, 2008: 76).

Policy implementation is a way to implement a policy to be able to achieve a predetermined goal. Policy in the education sector is used to understand the policy itself, which is part of public policy (Solichin, 2015: 155-156). The policy implementation process is a very decisive process. This process is important because the end of all policies that have been taken is always at the implementation stage. If the policy formulation has been made very good, but there is no follow-up in the form of implementation of the formulated policy, it is a futile effort and has no benefits (Hasbullah, 2015: 91).

The reason for the need for policy implementation, according to Quade (1984: 310) is to prove that in implementing the policy, there are actions, interactions, and reactions to the policy implementation factors. Quade stated that in the ideal policy implementation process will occur interactions and responses from the implementing organizations, targeted groups, and environmental factors that result in the emergence 
of pressure followed by bargaining or transaction actions. Quade illustrates that there are four variables that need to be considered in the analysis of the implementation of public policies, namely: 1) Policies that are dreamed of, namely patterns of interaction dreamed of so that people who set policies try to realize; 2) targeted groups, namely the subjects that are expected to adopt new patterns of interaction through policies and the subjects that must change to meet their needs; 3 ) organizations that carry out, which are usually in the form of units or work units of the government bureaucracy that are responsible for implementing policies; and 4) environmental factors, namely system elements in the environment that affect the policy implementation.

Al-Washliyah Educational Council Policy of the Big Board drafted in the form of a Decree. After making a regulation/policy decree, it will socialized to the regions. AlWashliyah Educational Council Policy of the Big Board went down to the areas, then invited both at the regional, regency and city levels. After the decree issued by the AlWashliyah Educational Council has released, all educational institutions in Al-Washliyah had to carry out well, including madrasah Aliyah. Among the examples of the AlWashliyah Educational Council's policies are about curriculum development, AlWashliyah subjects, Diniyah Curriculum, Imtihan Umumy, and other systems.

The Al-Washliyah curriculum first arranged on December 24, 1933. This arrangement was carried out because it should have been arranged in Madrasah Aliyah Al-Washliyah because of the rapid development of Al-Washliyah in several regions and accompanied by the establishment of madrasah in the various areas (Rozali, 2018: 35). Curriculum development carried out by the Al-Washliyah Educational Council must consider the matters that are urgent for Islamic education so that it has a responsibility in making curriculum development policies.

The Al-Washliyah Educational Council, before implementing the policy, first formulated the policy. Educational policy formulation is an effort to plan the success of education policies. Planning is a very urgent matter in various aspects of human life, every step, decision and human activity is essentially nothing but planning various kinds of things about the future (Taufiqurrahman, 2013: 42). Regarding the urgency of the planning, Allah the Almighty said in Q.S. Al-Hasyr/59: 18 namely: O you who believe! Fear Allah and keep your duty to Him. And let every person look to what he has sent forth for tomorrow, and fear Allah. Verily, Allah is Well-Acquainted with what you do (Al-Mahalli, 2012: 2422).

In the formulation of the implementation of the Al-Washliyah Educational Council policy in the curriculum development of the Al-Washliyah educational institution was by the rules made. The formulation is by the Al-Washliyah Basic Articles of Association and Bylaws in Article 37 concerning the Education Council's Task paragraph 1 that the Education Council is the only institution that manages the Education Sector. Based on this, those who have the right to make the policies regarding education, including the education curriculum development policy, are the Al-Washliyah Educational Council. Formulation of the curriculum can be found in the SPA in Chapter IV about the 
curriculum. In article 9 is mentioned several important points about the Al-Washliyah education curriculum, namely:

1. Al-Washliyah Primary and Secondary Education Curriculum is an arrangement of study materials and learning to achieve the goals of Al-Washliyah Primary and Secondary Education in the context of efforts to achieve the National Education Goals and Al-Washliyah Education goals.

2. The curriculum is a set of plans and arrangements regarding the purpose, content, and material of the lesson as well as the methods used as guidelines for the implementation of learning activities to achieve certain educational goals.

3. Al-Washliyah Primary and Secondary Education must include subjects on Islamic Education, Pancasila and Citizenship Education, Language, Mathematics, Science, Cultural Arts and Skills, Physical and Health Education, Local Content, AlWashliyahan.

4. Educational units at the level of Primary and Secondary Education can add several things, namely:

a. Curriculum content by the environmental conditions and characteristics of the school/madrasah concerned without reducing the applicable curriculum content.

b. Learning the material from the subjects according to their circumstances and needs.

The description above showed that the role of the Al-Washliyah Education Council in making policies for developing Islamic education curriculum is crucial. One of the determinants of the success of the objectives of Islamic education in Al-Washliyah educational institutions is the policy of the Al-Washliyah Educational Council.

\section{Conclusion}

Al-Washliyah is an organization born in North Sumatera. As a reform organization of Islamic education, Al-Washliyah has a high commitment to the development of the Madrasah Aliyah curriculum in North Sumatra. Madrasah Aliyah Al-Washliyah in North Sumatera is at least three types according to the curriculum used. The three types of Madrasah Aliyah are Mu'allimin; Qismul 'Aly; and Madrasah Aliyah Al-Washliyah.

Al-Washliyah Education Council Policy in developing Islamic education curriculum was by establishing policy implementation in the form of the decree, then socialized to be implemented. Among the education policies conducted by the AlWashliyah Educational Council in the development of the Madrasah Aliyah curriculum in North Sumatera are in the form of Al Washliyah subjects, Diniyah curriculum, and Imtihan Umumy.. 


\section{Bibliography}

Azra, Azyumardi et al. (2010). Varieties of Religious Authority: Changes and Challenges in 20th Century Indonesian Islam. Singapore: ISEAS Publishing.

Bogdan, Robert C., and Sari Knop Biklen. (1982). Qualitative Research for Education. London: Allyn and Bacon, Inc.

E.S. Quade. (1984). Analysis For Public Decisions. New York: Elsevier Science Publishers.

Suryadarma, Daniel, and Gavin W. Jones. (2013). Education In Indonesia. Singapore: ISEAS Publishing.

Al-Mahalli, Imam Jalaluddin dan Imam Jalaluddin As-Suyuthi. (2012). Tafsir Jalalin Berikut Asbaabun Nuzul Jilid 4. Bandung: Sinar Baru Algesindo.

Bungin, M. Burhan. (2011). Penelitian Kualitatif: Komunikasi, Ekonomi, Kebijakan Publik dan Ilmu Sosia.l Jakarta: Kencana.

Hasbullah. (2015). Kebijakan Pendidikan: Dalam Perspektif Teori, Aplikasi dan Kondisi Objektif Pendidikan di Indonesia. Jakarta: RajaGrafindo Persada.

Lexy J. Moleong. (2008). Metodologi Penelitian Kualitatif. Bandung: Remaja Rosdakarya.

Mujianto Solichin. (2015). Implementasi Kebijakan Pendidikan Dan Peran Birokrasi. Religi: Jurnal Studi Islam 6 (2): 155-156.

Pengurus Besar Al-Jam'iyatul Washliyah, Anggaran Dasar \& Anggaran Rumah Tangga dan Keputusan Muktamar XXI Al-Jam'iyatul Washliyah Priode 2015-2020.

Pengurus Besar Al-Jam'iyatul Washliyah. (2017). Peraturan Pelaksanaan Sistem Pendidikan AlWashliyah Bidang Pendidikan Dasar dan Menengah. Jakarta: ttp.

Rozali, Muhammad. (2018). Tradisi Keulamaan Al Jam'iyatul Washliyah Sumatera Utara. Yogyakarta: LKiS.

Sugiono. (2014) Memahami Penelitian Kualitatif. Bandung: Alfabeta.

Syafaruddin. (2008). Efektivitas Kebijakan Pendidikan. Jakarta: Rineka Cipta.

Taufiqurrahman. (2013). Prinsip-prinsip Administrasi Dalam Al-Qur'an. Medan: Perdana Publishing.

Tilaar, H.A.R. (2009). Kekuasaan dan Pendidikan: Manajemen Pendidikan Nasional dalam Pusaran Kekuasaan. Jakarta: PT. Rineka Cipta

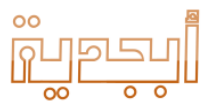

